\title{
STRATEGI BAITUL MAL WAT TAMWIL (BMT) \\ MASLAHAH CAPEM WANGKAL DALAM \\ MENGANTISIPASI KREDIT MACET \\ (Studi Kasus di BMT Maslahah Capem Wangkal Desa Wangkal Kecamatan \\ Gading Kabupaten Probolinggo)
}

\author{
Nuruddin Armanto \\ Email: armanto99@gmail.com \\ Universitas Zainul Hasan Genggong \\ Ayu Rizki Sholeha \\ Universitas Zainul Hasan Genggong
}

\begin{abstract}
Borrowing and lending is one of the economic activities carried out by financial institutions, especially the BMT Maslahah CapemWangkal cooperative, the BMT Maslahah Capem Wangkal cooperative business activities include the provision of credit. BMT cooperative Maslahah Capem Wangkal as a distributor and provider of credit funds for the community that does not always run smoothly, there are times when debtors do not fulfill obligations according to the agreed time (default). The formulation of the problem in this study are: 1) What causes the occurrence of bad credit in Baitul Maal Wat Tamwil Maslahah Wangkal Sub-Branch? and 2) what is the strategy to anticipate customers of Baitul Maal Wat Tamwil Maslahah Wangkal Sub-Branch Office to avoid bad credit? Objective 1) to find out the causes of bad credit in Baitul Maal Wat Tamwil Maslahah Wangkal Sub-Branch and 2) to find out the strategy used by BMT Maslahah Capem Wangkal in anticipating the occurrence of bad credit.
\end{abstract}

Keywords: Bad Credit, Strategy, BMT 


\section{PENDAHULUAN}

Strategi merupakan proses penentuan rencana para pemimpin puncak yang berfokus pada tujuan jangka panjang organisasi disertai penyusunan suatu cara atau upaya bagaimana agar tujuan tersebut dapat dicapai. Konsep strategi dapat didefinisikan berdasarkan dua perspektif yang berbeda yaitu : dari perspektif apa yang ingin dilakukan organisasi (intends to do) dan perspektif apa yang organisasi akhirnya ingin dilakukan (eventually does).

Lembaga keuangan syariah di Indonesia telah berkembang sangat pesat dengan seiringnya waktu kebutuhan masyarakat juga semakin meningkat. Salah satu lembaga keuangan yang sedang berkembang pesat adalah Bait Almaal Wa At-tamwil atau BMT. Baitul Maal Wat Tamwil Maslahah Capem Wangkal menumbuh kembangkan bisnis usaha mikro dan kecil dalam rangka mengangkat derajat dan martabat serta membela kepentingan kaum fakir miskin di Indonesia.

BMT Maslahah Capem Wangkal merupakan lembaga keuangan syariah, bukan bank yang berdiri berdasarkan syariah islam dan bergerak dalam upaya memberdayakan umat. BMT Maslahah Capem Wangkal, Baitul Tamwil ini bergerak dalam bentuk pinjaman atau pembiayaan usaha dengan sistem jual beli, bagi hasil maupun jasa. ${ }^{1}$ BMT Maslahah Cabang Pembantu Wangkal adalah salah satu BMT Maslahah yang sudah berkembang di Indonesia cabangnya sudah tersebar dimana-mana termasuk di daerah kraksaan, penelitian hendak bermaksud untuk menjadikan BMT Maslahah Capem Wangkal sebagai lokasi penelitian. Selain itu lokasi BMT Maslahah Capem Wangkal letaknya yang sangat strategis yaitu berada didekat kecamatan Wangkal dan juga berdekatan dengan pasar Wangkal. Dengan lokasi yang strategis ini BMT Maslahah Capem Wangkal menjadi salah satu alternative peminjaman atau pembiayaan bagi para pedagang pasar, pedagang kaki lima yang berada di sekitar pasar, dan masyarakat sekitar Wangkal.

Adapun garpu analisis terhadap kelayakan suatu pembiayaan antara lain dengan menggunakan 5'C principle, yang terdiri dari character, capacity, capital, condition of economy, dan collateral.Character merupakan penilaian BMT terhadap sifat dan karakter individu anggota. Apabila anggota dinilai baik, maka pengajuan pemohonan pembiayaan diterima oleh pihak BMT Maslahah Capem Wangkal. Begitupun sebaliknya, apabila anggota memiliki karakter yang kurang baik, maka pengajuan permohonan akan ditolak oleh pihak BMT. Capacity merupakan kemampuan anggota menjalankan usaha

${ }^{1}$ Muhammad Ridwan, Manajemen BaitulMaal Wat Tamwil(BMT) (Yogyakarta:UUI Press 2005),hlm. 126. 
guna mendapatkan laba sehingga dapat mengembalikan pinjaman/pembiayaan dari laba yang dihasilkan. ${ }^{2}$

BMT Maslahah Capem Wangkal sebagai penyalur dan penyedia dana kredit bagi masyarakat tidak selalu berjalan lancar, ada kalanya debitur tidak memenuhi kewajiban sesuai waktu yang disepakati (wanprestasi). BMT Maslahah Capem Wangkal dapat melakukan berbagai upaya atau strategi untuk menanggulangi masalah kredit macet, seperti pendekatan dengan calon anggota, atau mengevaluasi asal-usul calon anggota atau sudah menjadi anggotannya, sehingga pembiayaan dapat terlaksana dalam mencapai sebuah tujuannya dan supaya dikemudian hari tidak terjadi kredit macet.

Dari uraian latar belakang di atas, mendorong peneliti akan melakukan penelitian lebih mendalam mengenai strategi yang diterapkan oleh BMT Maslahah Capem Wangkal Dalam Mengantisipasi wanprestasi. Berdasarkan penjelasan di atas, peneliti akan melakukan penelitian dengan judul :

"Strategi BMT Maslahah Capem Wangkal Dalam Mengantisipasi Kredit Macet" (Studi Kasus di BMT Maslahah Capem Wangkal Desa Wangkal Kecamatan Gading Kabupaten Probolinggo).

\section{KAJIAN PUSTAKA}

\section{Pengertian Strategi}

Strategi adalah ilmu dan seni menggunakan semua sumber daya bangsa-bangsa untuk melaksanakan kebijaksanaan tertentu dalam perang dan damai. Ilmu dan seni memimpin bala tentara untuk menghadapi musuh dalam perang, dalam kondisi yang menguntungkan, saran rencana untuk memperbesar pengaruh terhadap pesan, baik dalam jangka pendek atau jangka panjang, yang didasarkan pada riset, pesan, penilaian, perencanaan produk, promosi dan perencanaan penjualan serta distribusi. ${ }^{3}$ Pengertian strategi adalah ilmu siasat perang, muslihat untuk mencapai sesuatu. ${ }^{4}$

Pengertian strategi memberikan beberapa dimensi strategi diantaranya: ${ }^{5}$

a. Strategi sebagai penentu tujuan jangka panjang, program kerja, dan alokasi sumber daya.

b. Strategi sebagai penentu aspek keunggulan organisasi.

c. Strategi sebagai penentu tugas manajerial

d. Strategi sebagai pola pengambilan keputusan yang saling meningkat 2015),hlm. 81

${ }^{2}$ Binti Nur Asiyah, Manajemen Pembiayaan Bank Syariah (Yogyakarta: Kalimedia,

${ }^{3}$ Departemen Pendidikan dan kebudayaan, kkbi, (Balai Pustaka, 1999), cet. 10

${ }^{4}$ M. Dahlan Al Barry, Kamus Ilmiyah popular, (Surabaya: Arkota, 2001), hlm. 733

${ }^{5}$ Asep Ruli Radiman R. Konsep Strategi Pemikiran dan logika,dalam

asepruli.blogspod.com//2009_06_01 archive.hlmn. di akses pada 21 Januari 2019. 
e. Strategi sebagai pernyataan keinginan strategis

f. Strategi sebagai upaya mengalokasikan sumber daya untuk mengembangkan keunggulan daya saing yang berkesinambung. Dalam kompetensi terkait erat dengan sumber daya organisasi.

\section{Manajemen Strategi}

Manajemen Strategi merupakan sekumpulan keputusan dan tindakan manajerial yang menentukan kinerja perusahaan dalam jangka panjang. manajemen strategi merupakan proses atau rangkaian kegiatan pengambilan keputusan yang bersifat mendasar dan menyeluruh disertai penetapan cara melaksanakannya, yang dibuat oleh pimpinan dan diimplementasikan seluruh jajaran di dalam suatu organisasi, untuk mencapai tujuan. Menurut Nagasimha Kanagal. ${ }^{6}$ One of the major objectives of marketing strategy is to enhance the long-term financial performance of a firm. As such competitive marketing strategy serves to improve financial performance of the firm through the route of sustainablecompetitiveadvantages. Artinya :Salah satu utama tujuan dari strategi pemasaran adalah untuk meningkatkan kinerja keuangan jangka panjang dari suatu perusahaan. Sebagai seperti strategi pemasaran kompetitif berfungsi untuk memperbaiki kinerja keuangan perusahaan melalui rute keunggulan kompetitif yang berkelanjutan.

Selanjutnya, perusahaan harus menciptakan keputusan strategis keputusan ini harus mampu menjawab dua pertanyaan utama: ${ }^{7}$

a. Industri apa yang digeluti perusahaan.

b. Bagaimana perusahaan harus bersaing di industri tersebut.

Menurut Sondang P. Siagian, "manajemen strategi berperan penting didalam suatu organisasi terutama dalam menciptakan kultur organisasi yang secara moral dan etika dapat dipertanggung jawabkan. ${ }^{8}$

\section{Macam-Macam Strategi}

Bentuk-bentuk strategi, diantaranya adalah:

\section{a. Strategi Pemasaran}

Strategi pemasaran adalah pengambilan keputusan mengenai biaya pemasaran, alokasi pemasaran, bauran pemasaran, yang berhubungan dengan keadaan lingkungan dan persainagan dalam bisnis. ${ }^{9}$

b. Strategi operasional

\footnotetext{
${ }^{6}$ Nagasimha kanagal, 2004, role of relationship marketing in competitive marketing strategy, journal of management and marketing research, hlm 02 (http://www.aabri.com). Di akses pada 15 Januari 2019.

${ }^{7}$ Ibid.

${ }^{8}$ Prof. Dr. Sondang P. Siagian, MPA, Manajemen Srtrategik, (Jakarta:Sinar Grafika
} Offset, 2003), hlm. 10.

${ }^{9}$ Mohammad Tohir, 2014 , Ketahui 6 Strategi pemasaran yang

Efekif,(www.lebahmaster.com) di akses pada tanggal 21 Januari 2019. 
Strategi operasinal adalah suatu visi fungsi operasi yang menentukan pengambilan keputusan operasi yang konsisten dan suatu keunggulan bersaing bagi perusahaan. Strategi operasional sendiri dari empat komponen yaitu: misi (mission), tujuan (objectiver), kemampuan khusus (destrictive competence) dan kebijakan (policy)

c. Strategi Teknologi

Strategi teknologi bertujuan untuk meningkatkan kinerja operasional melalui penggunaan substrategi seprti pengembangan teknologi dari internet, memperoleh teknologi baru, dan menggunakan peralatan teknologi informasi.

d. Strategi Manajemen Sumber Daya

Strategi sumber daya manusia bertujuan untuk meningkatkan kinerja operasional penggunaan substrategi seperi perencanaan rekrutmen, peyeleksian, dan perencanaan jalur kari karyawan, pendidikan, pengembangan keerampilan dan peningkaan parisipasi.

e. Perencanaan Strategi

Perencanaan strategi adalah sebuah proses yang berlangsung dimana perusahaan mengembangkan sebuah strategi yang konsisten dengan lingkungannya yaitu: industri, lingkungan yang kompetitif, sumber daya, nilai managerial, dan organisasi. ${ }^{10}$

4. Definisi Baitul Mal Wat Tamwil

Baitul Mal Wat Tamwil (BMT) merupakan balai usaha mandiri terpadu yang isinya berinikan lembaga bait al-mal wa al-tamwil, yakni merupakan lembaga usaha masyarakat yang mengembangkan aspek-aspek produksi dari investasi unuk meningkatkan kualitas kegiatan ekonomi dalam skala kecil dan menengah. ${ }^{11}$ Baitul Mal Wat Tamwil (BMT) dapat pula dikategorikan dengan koperasi syariah yakni lembaga ekonomi yang berfungsi untuk menarik, mengelola dan menyalurkan dana dari, oleh dan untuk masyarakat.

Baitul Mal Wat Tamwil (BMT) merupakan lembaga pendukung kegiatan ekonomi masyarakat bawah dan menengah dengan berlandasan syariah yang menpunyai tujuan meningkatkan kualitas usaha ekonomi untuk kesejahteraan masyarakat dan mempunyai sifat usaha yakni usaha bisnis, mandiri, ditumbuh kembangkan dengan swadaya yang dikelola secara profesional. Sedangkan dari segi aspek Baitul Maal lebih mengarah

\footnotetext{
${ }^{10}$ Tuti_Ajalah, straegi teknologi, di kutip dari https://tutisarmasinaga.wordpress.com/2012/06/23/strategi-teknologi/ di akses pada 16 januari 2019.

${ }^{11}$ Muhammad Hasan Ridwan, BMT Bank Islam Instrumen Lembaga Keuangan Syariah (Bandung : Pustaka Bani Quraisy, 2004), hlm. 29.
} 
pada usaha-usaha pengumpulan dan penyaluran dana yang non-profit, seperti zakat, infak, dan sedekah.

\section{Pengertian Kredit}

Kredit adalah pinjaman uang dengan pembayaran secara mengangsur, atau dengan kata lain 'kredit' secara harfiah dapat diartikan; pinjaman uang yang dikembalikan secara mengangsur dengan batas waktu tertentu yang diizinkan oleh bank atau badan usaha lain. ${ }^{12}$ Usaha lembaga keuangan perbankan atau badan usaha lain pada umumnya lebih menekankan pada kegiatan perkreditan, karena dapat memberikan keuntungan.

Menurut Supramono, ${ }^{13}$ kredit merupakan perjanjian pinjam-meminjam uang antara Baitul Mal Wat Tamwil sebagai debitur dengan nasabah sebagai debitur. Dalam perjanjian ini Baitul Mal Wat Tamwil sebagai pemberi kredit percaya terhadap nasabahnya dalam jangka waktu yang disepakainya akan dikembalikan atau dibayar lunas. Tenggang waktu antara pemberian dan penerimaan kembali prestasi ini merupakan suatu hal yang abstrak, yang sukar diraba.

Dalam praktek perbankan, kredit-kredit yang dibarikan kepada nasabahnya dapat dilihat dari berbagai segi, sebagai berikut :

a. Menurut jangka waktunya.

b. Menurut kegunaannya

Dilihat dari kegunaannya juga bisa digolongkan dalam tiga golongan yaitu :

1) Kredit investasi

2) Kredit modal kerja

3) Kredit profesi

c. Menurut pemakaiannya

1) Kredit Konsumtif

2) Kredit produktif

d. Menurut sektor yang dibiayai

Dalam memberikan kredit, Baitul Mal Wat Tamwil atau lembaga perkreditan lainnya wajib mempunyai keyakinan atas kemampuan dan kesanggupan debitur untuk melunasi hutangnya sesuai dengan yang diperjanjikan. Untuk mempeoleh keyakinan tersebut, maka sebelum memberikan kredit bank atau Baitul Mal Wat Tamwil harus memiliki prinsip analisa pra pembiayaan agar dalam menawarkan produk pembiayaan tidak akan menghadapi risiko. Terlebih risiko dalam keterlambatan

\footnotetext{
${ }^{12}$ Trisno Yuwono \& Silvita, I.S, Kamus Lengkap Bahasa Indonesia, Surabaya: Penerbit Arloka, (Lth), Hlm, 330.

${ }^{13}$ Gatot Supramono, Perbankan dan Masalah Kredit, (Jakarta:Rineka Cipta, 2009).

Hlm. 12
} 
pembayaran atau bahkan pembiayaan macet. Sehingga Baitul Mal Wat Tamwil BMT atau memiliki metode guna meminimalisir terjadinya risiko tersebut. Sebelum memberikan keputusan terhadap pengajuan, Baitul Mal Wat Tamwil atau BMT melakukan berbagai analisa pra pembiayaan. Analisa pra pembiayaan tersebut, antara lain :

a. Character : merupakan sifat atau karakter anggota terkait bagaimana sifat amanah, kejujuran, dan kepercayaan seorang anggota. Penilaian karakter bertujuan untuk mengetahui bagaimana karakter anggota pembiayaan.

b. Capacity : merupakan kemampuan nasabah untuk menjalankan usahanya guna memperoleh laba sehingga dapat mengembalikan pembiayaan dari laba yang dihasilkan. ${ }^{14}$

c. Capital yaitu penilaian terkait dengan jumlah modal yang dimiliki oleh anggota berupa aset.

d. Condition of economy merupakan analisa terkait keadaan perekonomian pada umumnya dan usaha yang dijalankan oleh si pemohon pembiayaan. Kondisi perekonomian baik atau buruknya mempengaruhi terhadap keberlangsungan usaha yang dijalankan oleh anggota.

e. Collateral merupakan aset anggota pembiayaan yang dijadikan sebagai jaminan atas pembiayaan yang diajukannya. Agunan atau jaminan yang diserahkan harus memiliki nilai jual dan kondisi fisik yang baik.

Kredit macet adalah suatu keadaan dimana seorang nasabah tidak mampu membayar lunas kredit tepat pada waktunya. Kemudian faktorfaktor yang mempengaruhi terjadinya kredit macet diantaranya adalah :

a. Faktor Internal

b. Faktor Eksternal

Untuk mengatasi kredit macet pihak Baitul Mal Wat Tamwil perlu melakukan peyelamatan sehingga tidak akan menimbulkan kerugian. Penyelamatan dapat dilakukan dengan memberikan keringanan berupa jangka waktu pembayaran atau jumlah angsuran terutama bagi kredit terkena musibah atau dengan melakukan penyitaan bagi kredit yang sengaja lalai untuk membayar. Penyelamatan terhadap kredit macet dilakukan dengan beberapa metode :

a. Rescheduling atau penjadualan kembali

b. Reconditioning

c. Recstructuring

\section{METODE PENELITIAN}

\footnotetext{
${ }^{14} \mathrm{Ibid}, \mathrm{hlm}, 81$.
} 
Pendekatan yang digunakan dalam penelitian ini adalah menggunakan pendekatan penelitian kualitatif. Kirk dan Miller mendefinisikan penelitian kualitatif sebagai tradisi tertentu dalam ilmu pengetahuan sosial yang secara fundamental bergantung dari pengamatan pada manusia baik dalam kawasannya maupun dalam peristilahannya. ${ }^{15}$

Sedangkan jenis penelitian ini termasuk jenis studi kasus (Case Study). Studi kasus adalah bagian dari metode kualitatif yang hendak mendalami suatu kasus tertentu secara lebih mendalam dengan melibatkan pengumpulan beraneka sumber informasi. Studi kasus ini merupakan studi kasus yang deskriptif yaitu bertujuan menggambarkan suatu, fakta atau realita. ${ }^{16}$

Deskriptif merupakan penelitian yang berusaha mendeskripsikan dan menginterpretasikan data-data yang ada, disamping itu penelitian deskriptif terbatas pada usaha mengungkapkan suatu masalah atau keadaan atau peristiwa sebagaimana adanya sehingga bersifat sekedar mengungkapkan atau memaparkan fakta. ${ }^{17}$ Jadi, yang dimaksud penelitian deskriptif dalam penelitian ini adalah penelitian yang mengungkapkan/memaparkan data yang telah diperoleh penelit yang berkaitan dengan "Strategi Baitul Maal Wat Tamwil Dalam Mengantisipasi Kredit Macet".

Pada penelitian lapangan yang digunakan peneliti adalah pendekatan kualitatif, peneliti bertindak sebagai instrumen sekaligus pengumpul data. Instrumen selain manusia (seperti: pedoman wawancara, pedoman observasi dan sebagainya) dapat pula digunakan, tetapi fungsinya terbatas sebagai pendukung tugas peneliti sebagai instrumen. Oleh karena itu, kehadiran peneliti adalah mutlak. ${ }^{18}$

Lokasi yang diambil oleh peneliti sebagai acuan untuk memperoleh data adalah BMT Maslahah Capem Wangkal yang berada di daerah desa wangkal bertempat di baratnya kantor kecamatan gading. Objek penelitian tertuju kepada nasabah BMT Maslahah Capem Wangkal.

Teknik pengumpulan data yang digunakan oleh peneliti pada penelitian ini, adalah sebagai berikut :
a. Wawancara
b. Observasi
c. Studi Dokumentasi

${ }^{15}$ Lexy J. Moleong, MetodologiPenelitianKualitatif EdisiRevisi (Bandung: PT Remaja Rosdakarya, 2005), hlm. 4

${ }^{16}$ J.R. Raco, Metode PenelitianKualitatifJenis, Karekteristik dan Keunggulannya (Jakarta: PT. Grasindo, 2010), hlm. 49-50

${ }^{17}$ Moh. Suhil, SistemEkonomi Syariah Dalam PengelolaanKoperasi (UGT) Usaha GabunganTerpaduSidogiriPasuruan, Skripsi, (Malang: FT-UIN Malang, 2010), hlm. 54

${ }^{18}$ Wahidmurni,cara mudah menulis proposal dan laporan penelitian lapangan pendekatan kualitatif dan kuantitatif, (skripsi tesis, dan disertasi)hlm. 30-31 
Analisis data adalah proses mencari dan menyusun secara sistematis data yang diperoleh dari hasil wawancara, catatan lapangan, dan bahanbahan lain, sehingga dapat mudah dipahami, dan temuannya dapat diinformasikan kepada orang lain. Analisis data dilakukan dengan mengorganisasikan data, menjabarkannya ke dalam unit-unit, melakukan sintesa, menyusun ke dalam pola, memilih mana yang penting dan yang akan dipelajari, dan membuat kesimpulan yang dapat diceritakan kepada orang lain. ${ }^{19}$

Sebagai tahapan akhir dari metode penelitian ini adalah menganlisis data. Data yang telah dikumpulkan melalui berbagai macam metode di atas masih merupakan data mentah sehingga perlu dikelola dan dianalisis. Dalam penelitian ini, pendekatan penelitiannya adalah kualitatif, sehingga dalam menganalisis data yang diperoleh dari data kualitatif hanya menggunakan anlisa deskriptif.

analisi data dibagi menjadi tiga, yaitu: pertama, tahap pendahuluan atau pengolahan data (kelengkapan data yang diperoleh, keterbatasan tulisan, kejelasan makna dan kesesuaian data satu dengan data lainnya). Tahap kedua, tahap pengorganisasian data yang merupakan inti dari analisis data. Tahap ketiga, tahap penemuan hasil. Tahap analisis data dimulai dari data awal yang diperoleh peneliti selama peneliti terjun ke lokasi penelitian. Hasil penelitian dikoreksi atau diperiksa atau dicek kembali dalam rangka mendapatkan keabsahan dan kredibilitas data yang diperoleh peneliti.

\section{TEMUAN DAN PEMBAHASAN}

\section{A. Produk Operasional Koperasi BMT Maslahah Capem Wangkal}

Dalam mencapai tujuannya untuk kemaslahatan umat, Koperasi Simpan Pinjam Syariah BMT Maslahah Capem Wangkal memiliki produkproduk yang dapat membantu masyarakat dalam memenuhi setiap kebutuhannya, produk-produk yang ditawarkan oleh BMT Maslahah Capem Wangkal kepada masyarakat antara lain :

1. Produk Simpanan

a. Tabungan Umum Syari'ah (keuntungan melimpah, bebas riba dan penuh berkah)

b. Tabungan Haji Al-Haromain/Umrah Al-hasanah (wujudkan niatan hati menuju tanah suci)

c. Tabungan Akikah(Tabungan aqiqah adalah tabungan untuk mempersiapkan acara aqiqah )

d. Tabungan Idul Fitri (tenang dan bahagia menjelang Idul Fitri)

${ }^{19}$ Sugiyono, Metode PenelitianPendidikanPendekatanKuantitatif, Kualitatif, dan $R \& D$ (Bandung: Alfabeta, 2008), hlm. 334 
e. Tabungan Pendidikan (meningkatkan kepercayaan dan kepedulian lembaga.

f. Tabungan Ziarah (Tabungan untuk keperluan ziarah wali )

g. Tabungan Qurban (indah niat melaksanakan ibadah qurban pada hari raya idul adha)

h. Tabungan walimah (tabungan persiapan pernikahan)

2. Produk Pembiayaan

a. Mudharabah

Adalah suatu bentuk peniagaan dimana pemilik modal menyetorkan modalnya kepada seseorang pengusaha (mudharib) untuk dikelola dengan pembagian keuntungan antara kedua belah pihak berdasarkan nisbah yang telah disepakati sebelumnya.

b. Murabahah

Adalah perjanjian jual beli antara BMT Maslahah Capem Wangkal dan nasabah di mana BMT Maslahah Capem Wangkal membeli barang yang diperlukan oleh nasabah dan kemudian menjualnya kepada nasabah yang bersangkutan sebesar harga perolehan ditambah dengan margin atau keuntungan yang disepakati antara BMT Maslahah Capem Wangkal dan nasabah.

c. Musyarakah

Adalah perjanjian di antara pemilik dana atau modal untuk dicampurkan pada usaha tertentu, dengan pembagian keuntungan di antara mereka berdasarkan nisbah yang disepakati sebelumnya.

d. Ijarah

Adalah perjanjian antara BMT Maslahah Capem Wangkaldan nasabah dalam memenuhi kebutuhan nasabah dalam bentuk sewa.

e. Qard

Adalah penyediaan dana pinjaman berdasarkan kesepakatan antara BMT Maslahah Capem Wangkal dan nasabah peminjam yang mewajibkan nasabah peminjam melunasi hutangnya setelah jangka waktu tertentu sesuai perjanjian.

\section{B. Produk Pembiayaan Murabahah diBMT Maslahah Capem Wangkal}

Produk pembiayaan murabahah di BMT Maslahah Capem Wangkalmerupakan produk terobosan yang ditawarkan oleh BMT Maslahah Capem Wangkalkepada masyarakat. Akan tetapi, tidak dipungkiri bahwa pada produk ini terdapat kredit macet. ${ }^{20}$

${ }^{20}$ Wawancara dengan AOP BMT Maslahah Capem Wangkal (Bpk.Ahmad Yani), tanggal 20 Juli 2019 
Tabel 3.1 Pembiayaan Murabahah 2019

\begin{tabular}{|c|c|c|}
\hline Pembiayaan murabahah & Anggota & NPF (\%) \\
\hline Lancar & 348 Orang & $80 \%$ \\
\hline Dalam Perhatian Khusus & 65 Orang & $15 \%$ \\
\hline Diragukan & 14 Orang & $3 \%$ \\
\hline Macet & 8 Orang & $2 \%$ \\
\hline
\end{tabular}

Data pembiayaan murabahah di BMT Maslahah Capem Wangkal pada tahun 2019 tercatat jumlah anggota pembiayaan produk murabahah sebanyak 435 jiwa. Dengan kategori jumlah pembiayaan lancar sebanyak 348 jiwa atau $80 \%$ dikatakan kredit lancar karena tidak ada keterlambatan dalam hal pembayaran, baik pengembalian pokok maupun bagi hasil yang telah disepakati. Kategori jumlah pembiayaan golongan DPK (Dalam Perhatian Khusus) sebanyak 65 jiwa atau 15\% dikatakan DPK karena anggota mengalami keterlambatan pembayaran angsuran pokok beserta margin sampai jangka waktu 90 hari, kategori jumlah pembiayaangolongan diragukan sebanyak 14 jiwa atau 3\% karena pembiayaan pelunasannya terdapat keterlambatan selama 180 hari sampai dengan 270 hari dari jangka waktu yang telah disepakati. Dan kategori jumlah pembiayaan golongan macet sebesar 8 jiwa atau 2\% karena pembiayaan mengalami kemacetan atau penundaan dalam hal pelunasan pembiayaan, baik pinjaman pokok maupun pembayaran bagi hasil yang telah ditetapkan selama lebih dari 270 hari dari waktu yang telah disepakati.Apabila didasarkan pada ketentuan yang dikerluarkan oleh Bank Indonesia, maka pihak lembaga keuangan diberikan batas jumlah pembiayaan bermasalah atau Non Performning Finance tidak lebih dari $5 \% .{ }^{21}$

\section{Penyebab Terjadinya Kredit Macet di BMT Maslahah Capem Wangkal}

Di dalam berbagai Lembaga Keuangan yang ada sudah pasti dan mungkin akan terjadi suatu masalah baik masalah itu terjadi secara disengaja oleh AOP ataupun tidak disengaja, termasuk juga di Koperasi BMT Maslahah Capem Wangkal ini terdapat masalah yang timbul salah satunya adalah faktor internal yang berupa analisa terhadap nasabah yang kurang bagus, sebagaimana yang diceritakan oleh bapak Samsul Arifin kepala cabang pembantu BMT Maslahah Capem Wangkal :

"Disebabkan karena kurangnya tingkat analisa daripihak AOPBMT

Maslahah Capem. Karena sebelum adanya keputusan apakah pengajuan anggota tersebut diterima atau ditolak, kita melakukan

${ }^{21}$ PBI No. 17/11/PBI/2015 Pasal 11 Ayat 2a 
analisa terlebih dahulu. Kalau analisa kita kurang, maka otomatis rentan terjadinya pembiayaan macet di BMT Maslahah Capem." ${ }^{22}$

Taksasinya atau taksiran yang diberikan BMT Maslahah Capem Wangkal melebihi $50 \%$ dari harga jaminan juga menjadi penyebab terjadinya kredit macet, sebagaimana yang diceritakan oleh bapak Samsul Arifin kepala cabang pembantu BMT Maslahah Capem Wangkal :

"Taksiran jaminan seharusnya tidak boleh melebihi 50\% dari harga jaminan, dan seharusnya pihak BMT Maslahah Capem Wangkal di dalam melakukan taksiran jaminan harus mencocokkan terlebih dahulu dengan harga yang di pasar. Jika nantinya nasabah telat melakukan angsuransedangkan hasil dari taksiran melebihi dari harga jaminan maka pihak BMT Maslahah Capem Wangkal besar kemungkinan akan terjadi kredit macet"

Pada dasarnya, kredit macet terjadi karena nasabah yang melakukan wanprestasi. Wanprestasi terjadi pada nasabah apabila si berhutang (debitur) tidak melakukan apa yang dijanjikannya. Jenis-jenis kredit macet berupa :

a. Menurut jangka waktunya.

b. Menurut kegunaannya.

c. Menurut pemakaiannya.

d. Menurut sektor yang dibiayai.

Ini juga terjadi di BMT Maslahah Capem Wangkal, sebagaimana yang diceritakan oleh bapak Ahmad Yani sebagai AOP :

"Iya kebayakan kasus terjadinya kredit macet di BMT Maslahah Capem Wangkal ini adalah telat dalam melakukan pembayaran angsuran, motor, terkadang angsuran yang seharusnya bulan sekarang dibayar, malah dibayar dibulan berikutnya, bahkan ada yang tidak membayar dua bulan, ya kami peringati biar tidak terulang kembali." 23

Wanprestasi adalah suatu kondisi dimana debitur berada dalam kondisi lalai atau terlambat dalam membayar. Contohnya, dalam hal ini debitur membutuhkan sepeda motor, untuk mendapatkannya debitur menyertakan agunan sertifikat berupa tanah sebagai jaminan kepada BMT Maslahah Capem Wangkal. Dinyatakan lalai apabila debitur tidak membayar kewajibannya setelah jatuh tempo yang dibuat dalam perjanjian

\footnotetext{
${ }^{22}$ Wawancara dengan kepala cabang pembantu Wangkal BMT Maslahah (Bpk. Samsul Arifin), tanggal 20 Juli 2019

${ }^{23}$ Wawancara dengan AOP BMT Maslahah Capem Wangkal (Bpk.Ahmad Yani), tanggal 20 Juli 2019
} 
tersebut atau seharusnya membayar angsuran pada bulan sekarang namun dibayar dibulan berikutnya.

Terjadinya kredit macet di BMT Maslahah Capem Wangkal disebabkan oleh beberapa faktor ekternal diantaranya :

a. Usahanya bangkrut: Keadaan bangkrut disebabkan usahanya menurun atau tertimpa musibah sehingga mengalami kerugian .

b. Ketidak terbukaan anggota pembiayaan: Menyembunyikan suatu hal yang dianggap penting penyebabnya karena adanya masalah yang menimpa sehingga kejujuran merosot.

c. Keadaan ekonomi yang menurun: Hasil usaha tidak seperti tahun sebelumnya, contohnya berbagai hasil pertanian menurun karena adanya beberapa faktor yaitu faktor cuaca, kesalahan manusia itu sendiri ataupun terkena serangan hama.

Sebagaimana yang diceritakan oleh bapak Abdullahsebagai AOA BMT Maslahah Capem Wangkal, ada beberapa faktor yang menyebabkan terjadinya kredit macet :

"Banyak faktor yang melatarbelakangi terjadinya kredit macet atau kegagalan dalam pelunasan pembiayaan di BMT Maslahah Capem Wangkal ini, yang dilakukan oleh beberapa nasabah yang agak sedikit nakal, diantaranya usahanya tidak berjalan lancar atau bangkrut, ketidakjujuran nasabah dibilangnya pembiayaan untuk usaha ternyata malah digunakan untuk yang lainnya, dan faktor pendapatan yang menurun tidak seperti bulan-bulan sebelumnya. Sehingga terjadilah molornya pembayaran atau pelunasan pembiayaan sehingga jatuh tempo. ${ }^{124}$

Faktor dari kredit macet beragam tersebut tergantung dari permasalahan yang dijumpai oleh masyarakat itu sendiri, maka disebabkannya terjadi kelalaian dan kejujuran akan menurun. Hal ini dapat sangat berpengaruh dalam hal keuangan dan mayoritas pendapatan masyarakat yang tidak menentu dan tidak mempunyai gaji tetap, sehingga tidak melaksanakan kewajiban dalam melakukan perjanjian yang telah disepakati sebelumnya dengan pihak BMT Maslahah Capem Wangkal.

Terjadinya kredit macet di BMT Maslahah Capem Wangkal disebabkan oleh faktor yang lain seperti, masyarakat menengah kebawah yang membutuhkan dana sedangkan masyarakat tersebut tidak memenuhi persyaratan pembiayaan, karena tidak memiliki agunan yang bisa diberikan

${ }^{24}$ Wawancara dengan AOA BMT Maslahah Capem Wangkal(Bpk.Abdullah), tanggal 
sehingga menggunakan jasa saudara atau kerabatnya yang menjadi nasabah di BMT Maslahah Capem Wangkal dan mempunyai cukup persyaratan untuk melakukan pembiayaan di BMT Maslahah Capem Wangkal, sedangkan hasil yang didapat dari pembiayaan tidak digunakan oleh nasabah tersebut, melainkan digunakan oleh masyarakat yang memyuruhnya atau menggunakan jasa ini sebagaimana yang diceritakan oleh bapak Samsul Arifin :

"Kasus yang lain yang kami temui, nasabah melakukan pembiayaan tapi hasil dari pembiayaan tersebut bukan untuk dirinya sendiri melainkan disuruh saudara atau temanya, ya nasabah kami memang yang melakukan pembiayaan tapi hanya digunakan sebagai jalan bagi mereka padahal yang menikmati hasil pembiayaan bukan nasabah itu sendiri, dari sinilah sering terjadi kredit macet atau wanprestasi karena kondisi antara nasabah dan masyarakat yang menyuruhnya terkadang mengalami masalah entah masyarakat tersebut belum ada uang atau usahanya bangkrut, meski keduanya sudah melakukan perjanjian tersendiri, sebelum akhirnya nasabah tersebut menyanggupi untuk melakukan pembiayaan atas namanya sendiri sedangkan hasilnya untuk masyarakat tersebut. Sehingga ketika datang masa untuk membayar cicilan terkadang nasabah masih menunggu dari masyarakat yang menggunakan hasil pembiayaan tersebut, bahkan terkadang nasabah menanggungnya terlebih dahulu dan bahkan jatuh tempo." 25

Karena rasa simpati yang amat besar serta eratnya tali persaudaraan, terkadang nasabah rela menggunakan namanya beserta agunannya untuk saudara atau kerabatnya yang membutuhkan dana pembiayaan, meski tengah jalan sering terjadi permasalahan diantara keduanya dalam pembayaran cicilan pembayaran sehingga terjadilah wanprestasi nasabah tersebut sehingga mengalami kredit macet dalam pembiayaan BMT Maslahah Capem Wangkal dikarenakan oleh beberapa faktor yang melatar belakanginya.

Adapun hasil penelitian yang diperoleh peneliti sebagaimana dikemukakan bab terdahulu, dengan cara pengamatan langsung mengenai penyebab terjadinya kredit macet melalui wawancara dengan nara sumber yang terkait, maka dapat diambil suatu kesimpulan sebagai berikut:

\footnotetext{
${ }^{25}$ Wawancara dengan kepala cabang pembantu Wangkal BMT Maslahah (Bpk. Samsul Arifin), tanggal 27 Juli 2019.
} 
Dari hasil wawancara kepada bapak Samsul Arifin selaku kepala Capem Wangkal secara keseluruhan mengenai penyebab terjadinya kredit macet di BMT Maslahah Capem Wangkal disebabkan karena adanya faktorinternal yang berupa analisa yang kurang bagus dari pihak AOP, jika analisa kita kurang maka akan renta mengalami masalah kredit macet. Dan selanjutnya dari taksasinya atau taksiran melebihi 50\% dari jaminan besarnya taksiran seharusnya tidak pernah terjadi karena akan beresiko tinggi bagi pihak BMT Maslahah Capem Wangkal.

Dari hasil wawancara kepada bapak Abdullah selaku AOA BMT Maslahah Capem Wangkal, disebabkan oleh pihak eksternal disegaja maupun tidak disengaja yang datang dari pihak nasabah yang mana dalam merintis usahanya tidak berjalan normal atau mengalami kebangkrutan, serta ketidakterbukaan dari anggota pembiayaan yang mengalami masalah sehinnga kejujurannya merosot, keadaan ekonomi yang menurun dari hasil pertanian mereka yang menurun dari tahun sebelumnya karena disebabkan oleh faktor cuaca dan terkena hama.

Dari hasil wawancara dengan bapak Samsul Arifin selaku kepala Capem Wangkal, terjadinya kredit macet di BMT Maslahah Capem Wangkal juga disebabkan oleh faktor eksternal dalam bentuk penyelewengan seperti, masyarakat menengah kebawah yang membutuhkan dana sedangkan masyarakat tersebut tidak memenuhi persyaratan pembiayaan, karena tidak memiliki agunan yang bisa diberikan sehingga menggunakan jasa saudara atau kerabatnya, sedangkan hasil yang didapat dari pembiayaan tidak digunakan oleh nasabah tersebut, melainkan digunakan oleh masyarakat yang memyuruhnya atau menggunakan jasanya.

\section{Strategi BMT Maslahah Capem Wangkal Dalam Mengantisipasi Kredit Macet}

Suatu strategi sangat diperlukan dalam proses menjalankan dan pendirian di suatu lembaga atau dalam suatu keorganisasian untuk mencapai visi dan misi tujuannya serta menghindari adanya kekeliruan atau masalah yang mungkin akan terjadi.

Strategi mengantisipasi dapat dilakukan dengan beberapa hal yang diketahui, terutama dari calon anggota atau nasabah BMT Maslahah Capem Wangkal, dalam mengantisipasi permasalahan atau kejadian yang tidak diinginkan oleh pihak BMT Maslahah Capem Wangkal, diantaranya strategi yang digunakan adalah strategi tenologi melalui kordinasi (Via SMS Gateway, Telepon, WA) melalui seluler kepada para nasabah yang sudah memasuki waktu pembayaran angsuran pembiayaan, sebagaimana yang diceritakan bapak Samsul Arifin : 
"Ya kami tidak mungkin satu-persatu ke nasabah untuk mengigatkan waktu pembayaran angsuran, terkadang kami mengingatkan dengan cara kordinasi (Via Telepon, SMS, WA) keseluruh nasabah, agar nasabah bisa mengetahui bahwa sekarang waktunya pembayaran angsuran." 26

Dengan cara strategi teknologi melalui kordinasi (Via SMSGateway, Telepon, WA) ini secara tidak langsung sebagai pengingat untuk nasabah bahwa sudah waktunya pembayaran agunan atau pelunasan pembiayaan, sehingga nasabah tidak mungkin lupa dan melalaikan pembayaran angsuran. Secara tidak langsung dengan demikian nasabah akan membayar dan menghindari terjadinyab pembiayaan kredit macet di BMT Maslahah Capem Wangkal.

Sebagaimana yang dijelaskan oleh salah satu nasabah atau debitur setelah melakukan wawancara dengan bapak kepala capem wangkal adalah:

"Ya, kami akan mendapat pesan dari BMT Maslahah Capem Wangkal pesan tersebut melalui SMS, jika telah masuk waktu pembayaran angsuran yang kami pimjam, sehingga kami mengingatnya untuk melakukan pembayaran pinjaman yang telah diberikan oleh pihak BMT Maslahah Capem Wangkal."27

Strategi yang lain yang dilakukan oleh BMT Maslahah Capem Wangkal agar tidak mengalami masalah kredit macet adalah strategi operasional yang berupa jaminan pembiayaan, jaminan atau agunan disini sangat penting, agar BMT Maslahah Capem Wangkal bisa meminimalisir terjadinya kredit macet, agunan disini berfungsi sebagai alat mengantisipasi jika nantinya pihak nasabah melakukan wanprestasi dan tidak mampu melunasi angsuran pembiayaan lagi, sehingga secara tidak langsung agunan menjadi milik BMT Maslahah Capem Wangkal sebagai penutup ata pembiayaan yang mengalami masalah sehingga terjadi kredit macet, dan ini sesuai dengan perjanjian yang ditandatangi oleh kedua pihak, sebagaimana yang diceritakan oleh bapak Samsul Arifin selaku Kepala BMT Maslahah Capem Wangkal :

"Terkait adanya jaminan itu sangat penting, apabila nanti kedepan ada permasalahan pelunasan maka jaminan tersebut otomatis menjadi hak BMT Maslahah Capem Wangkal, sebagaimana

\footnotetext{
${ }^{26}$ Wawancara dengan kepala cabang pembantu Wangkal BMT Maslahah (Bpk. Samsul Arifin), tanggal 27 Juli 2019.

${ }^{27}$ Wawancara dengan nasabah pembiayaan BMT Maslahah Capem Wangkal (Bpk. Romi Abrori), tanggal 27 Juli 2019.
} 
kesepakatan antara pihak BMT Maslahah Capem Wangkal dan nasabah diawal sebelum pencairan, apabila terjadi permasalahan pelunasan atau jatuh tempo dan nasabah tidak mampu membayar maka jaminan itu menjadi milik pihak BMT Maslahah Capem, misalnya jaminannya BPKB sepeda motor otomatis sepeda motor mereka akan kami sita karena kami sudah memiliki hak terhadap sepeda motor tersebut sesuai perjanjian yang sudah disetujui oleh nasabah. ${ }^{128}$

Jadi jaminan disini menjadi alat yang sangat penting agar nantinya, kredit macet atau permasalahan di dalam pelunasan pembiayaan dapat diantisipasi karena secara tidak langsung jika nasabah lalai dan tidak mampu melunasi maka pihak BMT Maslahah Capem Wangkal masih bisa menutupi pembiayaan tersebut dengan jaminan yang telah disetor oleh pihak nasabah, dan nasabah akan berfikir panjang agar jaminan tersebut tidak disita sehingga secara tidak langsung nasabah akan terhindar dari perbuatan wanprestasi. Dan calon anggota dan nasabah harus menyertakan berbagai persyaratan jika jaminan berupa agunan BPKB sebagai berikut :

a. Bersedia menjadi anggota BMT. Maslahah Capem Wangkal

b. Memiliki usaha dan atau berpenghasilan tetap

c. Mengisi formulir pembiayaan

d. Melengkapi persyaratan administratif:

e. Foto copy KTP suami istri 3 Lembar

f. Foto copy KK 2 Lembar

g. Foto copy surat nikah 2 Lembar

h. Foto copy agunan ( STNK.BPKB)

i. Melampirkan slip gaji bagi PNS

Selain itu penyesuaian STNK dengan nomor polisi dan nomor mesin kendaraan juga mutlak dilakukan agar data yang didapat benar-benar valid, sebagaimana yang diceritakan oleh bapak Samsul Arifin :

"Hal-hal mengenai jaminan atau agunan harus detail kami cermati jangan sampai kami tertipu, salah satu caranya mencocokkan nomor polisi kendaraan yang ada di dalam kendaraan, serta nomor rangka mesin yang ada di STNK dengan yang ada di dalam kendaraan, jika sesuai maka kami terima. ${ }^{129}$

\footnotetext{
${ }^{28}$ Wawancara dengan kepala cabang pembantu Wangkal BMT Maslahah (Bpk. Samsul Arifin), tanggal 24 Juli 2019.

${ }^{29}$ Wawancara dengan kepala cabang pembantu Wangkal BMT Maslahah (Bpk. Samsul Arifin), tanggal 24Juli 2019.
} 
Pentingnya analisa kendaraan serta mencocokkan antara nomor yang tertera di STNK dengan yang ada di kendaraan sangat penting dilakukan demi menghindari kecurangan yang dilakukan oleh calon anggota atau nasabah, sehingga jika nantinya nasabah melakukan wanprestasi dan terjadi kredit macet, maka akan dilakukan penyitaan agunan oleh pihak BMT Maslahah Capem Wangkal dan bukti yang dimiliki BMT Maslahah Capem Wangkal sudah kuat yaitu kecocokan antara STNK dengan nomor kendaraan. Sedangkan jika jaminan tersebut berbentuk sertifikat atau agunan sertifikat maka harus dinotariskan terlebih dahulu dan harus atas nama sendiri, sebagaimana yang diceritakan oleh bapa Samsul Arifin :

"Untuk jaminan sertifikat tanah, maka kami melakukan berbagai analisa diantaranya cek tempat atau letak tanah dan cek di notaris apakah sertifikat ini asli dan benar milik nasabah, jika tidak dilakukan ke notaris kami takut jika setifikat itu palsu dan bukan miliknya nasabah. ${ }^{30}$

Jaminan yang berupa sertifikat kemudian dibuat akta hak ketanggungan oleh notaris agar nantinya benar-benar dapat dilakukan penyitaan oleh BMT Maslahah Capem Wangkal, jika debitur (berhutang) melakukan wanprestasi.

Jika pada suatu saat terjadi yang tidak diinginkan maka, dalam menghindari kredit macet terdapat beberapa langkah yang dilakukan oleh BMT Maslahah Capem Wangkal yang dilakukan adalah peniagaan dengan mengadakan pendekatan lingkungan calon nasabah pembiayaan dengan mendatangi rumahnya, kemudian memberikan surat pemberitahuan atau surat peringatan pertama (SP.1) setelah dua bulan tidak membayar, pihak BMT Maslahah Capem Wangkal akan memberikan surat peringatan kedua (SP.II) setelah itu jika nasabah masih tetap tidak membayar maka pihak BMT Maslahah Capem Wangkal akan memberikan surat ketiga (SP.III) Setelah itu langkah terakhir yang akan dilakukan pihak BMT Maslahah Capem Wangkal adalah meminta surat penyerahan jaminan kemudian menjual bersama jaminan tersebut untuk melunasi pinjaman di BMT Maslahah Capem Wangkal. Sebagaimana yang diceritakan oleh bapak Samsul Arifin :

"Jika terjadi kredit macet disini, maka pertama kami akan memberikan surat peringatan sampai tiga kali berturut-turut namun

\footnotetext{
${ }^{30}$ Wawancara dengan kepala cabang pembantu Wangkal BMT Maslahah (Bpk. Samsul Arifin), tanggal 24 Juli 2019.
} 
pada akhirnya nasabah belum juga membayar anggsuran maka jaminan tersebut akan kami sita, dan akan kami jual untuk melunasi pembiayaan nasabah yang wanprestasi atau yang telat membayar anggsuran. ${ }^{131}$

Surat peringatan tersebut akan berfungsi agar nasabah berkeinginan untuk membayar angsuran, namun jika sampai surat peringatan ketiga kalinya maka yang terakhir pihak BMT Maslahah Capem Wangkal akan melakukan penyitaan jaminan, dan ini dilakukan untuk menutupi kekurangan angsuran yang ditanggung oleh pihak nasabah, namun apabila di kemudian hari jika debitur (berhutang) ada niat dan berkeinginan untuk membayarnya maka, diadakan akad ulang untuk semua akad agar tidak tidak terjadi lagi kasus bermasalah di kemudian hari.

Suatu strategi sangat diperlukan dalam proses menjalankan dan pendirian di suatu lembaga atau dalam suatu keorganisasian untuk mencapai visi dan misi tujuannya serta menghindari adanya kekeliruan atau masalah yang mungkin akan terjadi seperti yang dilihat dari tinjauan penelitian pada tabel 3.1 mengenai pembiayaan bermasalah dengan angka yang cukup sedikit. Mengenai hal tersebut, maka BMT Maslahah Capem Wangkal menerapkan beberapa strategi mengantisipasi agar kredit macet tidak terjadi peningkatan. Strategi tersebut antara lain.

Dari hasil wawancara kepada bapak Samsul Arifin selaku kepala Capem Wangkal pada BAB III halaman 62,strategi mengantisipasi dapat dilakukan dengan beberapa hal yang diketahui, terutama dari calon anggota atau nasabah BMT Maslahah Capem Wangkal, dalam mengantisipasi permasalahan atau kejadian yang tidak diinginkan oleh pihak BMT Maslahah Capem Wangkal, diantaranya strategi yang digunakan adalah strategi tenologi melalui kordinasi (Via SMS Gateway, Telepon, WA) melalui seluler kepada para nasabah yang sudah memasuki waktu pembayaran angsuran pembiayaan, dan tidak mungkin mendatangi rumah masing-masing dari nasabah pembiayaan.

Dan dari pemamparan wawancara dengan bapak Romi Abrori pihak nasabah, di BMT Maslahah Capem Wangkal mengatakan bahwa ia mendapatkan pesan dari pihak BMT Maslahah Capem Wangkat terkait waktu pembayaran angsuran yang telah ia pinjam telah tiba.

\footnotetext{
${ }^{31}$ Wawancara dengan kepala cabang pembantu Wangkal BMT Maslahah (Bpk. Samsul Arifin), tanggal 27 Juli 2019.
} 
Dari hasil wawancara kepada bapak Samsul Arifin selaku kepala Capem Wangkal, strategi yang lain yang dilakukan oleh BMT Maslahah Capem Wangkal agar tidak mengalami masalah kredit macet adalah strategi operasional yang berupa jaminan pembiayaan, jaminan atau agunan disini sangat penting, agar BMT Maslahah Capem Wangkal bisa meminimalisir terjadinya kredit macet, agunan disini berfungsi sebagai alat mengantisipasi jika nantinya pihak nasabah melakukan wanprestasi dan tidak mampu melunasi angsuran pembiayaan lagi, sehingga secara tidak langsung agunan menjadi milik BMT Maslahah Capem Wangkal sebagai penutup atas pembiayaan yang mengalami masalah sehingga terjadi kredit macet, dan ini sesuai dengan perjanjian yang ditandatangi oleh kedua pihak.

Dari hasil wawancara kepada bapak Samsul Arifin selaku kepala Capem Wangkal, mengatakan jika pada suatu saat terjadi yang tidak diinginkan maka, dalam menghindari kredit macet terdapat beberapa langkah yang dilakukan oleh BMT Maslahah Capem Wangkal yang dilakukan adalah mengadakan pendekatan dengan lingkungan calon nasabah pembiayaan dengan mendatangi rumahnya, kemudian memberikan surat pemberitahuan atau surat peringatan pertama (SP.1) setelah dua bulan tidak membayar, pihak BMT Maslahah Capem Wangkal akan memberikan surat peringatan kedua (SP.II) setelah itu jika nasabah masih tetap tidak membayar maka pihak BMT Maslahah Capem Wangkal akan memberikan surat ketiga (SP.III) Setelah itu langkah terakhir yang akan dilakukan pihak BMT Maslahah Capem Wangkal adalah meminta surat penyerahan jaminan kemudian menjual bersama jaminan tersebut untuk melunasi pinjaman di BMT Maslahah Capem Wangkal.

Berdasarkan hasil penelitian bahwa strategi mengantisipasi kredit macet yang diterapkan di BMT Maslahah Capem Wangkal terdapat beberapa pembiayaan yang sudah teratasi. Strategi mengantisipasi kredit macet yang diberlakukan di BMT Maslahah Capem Wangkal pada produk pembiayaan Murabahah sudah dilakukan dengan baikkarenadidukung dengan tingkat ketegasan dan kedisiplinan oleh pihak BMT Maslahah Capem Wangkal dan anggota yang memiliki i'tikad yang baik.

\section{KESIMPULAN}

Dari penjelasan yang terdapat dari sebuah skripsi ini terdapat kesimpulan yang dapat peneliti uraikan yaitu sebagai berikut :

1. Faktor yang menyebabkan terjadinya kredit macet di BMT Maslahah Capem Wangkal adalahfaktor internal dan faktor eksternal. Faktor internal yaitu dari pihak AOP dalam menganalisa calon nasabah yang kurang bagus, taksasinya atau taksiran melebihi 50\% dari jaminan juga 
menyebabkan terjadinya kredit macet, selain itu faktor eksternal disebabkan oleh ketidak sengajaan maupun sengaja yang datang dari pihak nasabah yang dalam usaha yang dirintis oleh nasabah mengalami kegagalan juga mempengaruhi adanya masalah karena nasabah mengalami kerugian atau kebangkrutan, maka dari itu pendapatan yang di dapatkan dari hasil usaha mereka menjadi menurun atau tidak ada hasil sehingga untuk membayar angsuran nasabah mengalami kendala bahkan tidak mampu membayar, dan terjadinya kredit macet juga merupakan penyebab adanya faktor eksternal yang disebabkan oleh penyelewengan dari nasabah yang melakukan pembiayaan namun hasil dari pembiayaan tersebut bukan untuk dirinya sendirin melainkan untuk saudara atau kerabatnya sehingga dalam pembayarannya terjadi permasalahan antara nasabah dan saudaranya tersebut sehingga menjadi masalah dan penyebabnya adalah kesulitan pencairan dana sehingga terjadi kredit macet di BMT.

2. Jumlah pembiayaan yang bermasalah pada produk Murabahah di BMT Maslahah Capem Wangkal mencapai angka kurang dari 5\% sebagaimana batas NPF yang telah ditetapkan. Meninjau hal tersebut kondisi BMT Maslahah Capem Wangkal dapat dikatakan sehat. Oleh karena itu, strategi pengantisipasian kredit macet yang dilakukan oleh pihak BMT Maslahah Capem Wangkal, antara lain adalah : Strategi dan langkah yang digunakan oleh BMT Maslahah Capem Wangkal dalam mengantisipasi kredit macet adalah strategi teknologi dengan melalui kordinasi (Via SMS Gateway, Telepon, WA), dan strategi operasianal dengan meminta jaminan atau agunan pada nasabah. Dan apabila nantinya terjadi kredit macet maka dari pihak BMT Maslahah Capem Wangkal akan menuliskan surat SP (surat peringatan) dan akan dilanjutkan dengan penyitaan sebagai langkah terakhir yang dilakukan oleh pihak BMT Maslahah Capem Wangkal.

Saran-Saran

Untuk pihak BMT Maslahah Capem Wangkal :

1. Perlunya meningkatkan pengawasan dan melihat kemampuan debitur serta itikad debitur sebelum dan setelah mendapatkan dana kredit dari BMT Maslahah Capem Wangkal.

2. Perlunya manajemen pembiayaan yang baik, khususnya dalam menganalisa calon nasabah baru agar kredit macet bisa teratasi dan diantisipasi dengan mudah. 


\section{DAFTAR PUSTAKA}

Al Barry, M. Dahlan. 2001. "Kamus Ilmiyah popular”. Surabaya: Arkota.

Ajalah, "Straegi Teknologi", di kutip dari https://tutisarmasinaga.wordpress.com/2012/06/23/strategi-teknologil. Di akses pada 16 januari 2019.

Asiyah, Nur. 2015. "Manajemen Pembiayaan Bank Syariah. Yogyakarta: Kalimedia.

Departemen Pendidikan dan kebudayaan. 1999. KKBI. Balai Pustaka.

Kanagal, Nagasimha. 2004. "Role Of Relationship Marketing In Competitive Marketing Strategy". Journal Of Management And Marketing Research, (http://www.aabri.com). Di akses pada 15 Januari 2019.

Moleong, Lexy J. 2005.“Metodologi Penelitian Kualitatif Edisi Revisi”. Bandung: PT Remaja Rosdakarya.

Raco, J.R. 2010. "Metode Penelitian Kualitatif Jenis, Karekteristik dan Keunggulannya”. Jakarta: PT. Grasindo.

Radiman R, Asep Ruli. "Konsep Strategi Pemikiran Dan Logika". asepruli.blogspod.com//2009 0601 archive.hlmn. Di akses pada 21 Januari 2019.

Ridwan, Muhammad. 2005. "Manajemen Baitul Maal Wat Tamwil" (BMT). Yogyakarta: UUI Press.

Ridwan, Muhammad Hasan. 2004. "BMT Bank Islam Instrumen Lembaga Keuangan Syariah”. Bandung : Pustaka Bani Quraisy.

Siagian. Sondang P. 2003. "Manajemen Srtrategik”. Jakarta: Sinar Grafika Offset

Silvita, Trisno Yuwono \& I.S. “Kamus Lengkap Bahasa Indonesia”. Surabaya: Penerbit Arloka.

Sugiyono. 2008. "Metode Penelitian Pendidikan Pendekatan Kuantitatif, Kualitatif, dan R\&D. Bandung: Alfabeta.

Suhil, Moh. 2010. "Sistem Ekonomi Syariah Dalam Pengelolaan Koperasi (UGT) Usaha Gabungan Terpadu Sidogiri Pasuruan”. Skripsi. Malang: FT-UIN Malang.

Supramono, Gatot. 2009. "Perbankan dan Masalah Kredit”. Jakarta:Rineka Cipta.

Tohir. Mohammad. 2014. "Ketahui 6 Strategi pemasaran yang Efekif”. (www.lebahmaster.com). di akses pada tanggal 21 Januari 2019.

Wahidmurni. "Cara Mudah Menulis Proposal Dan Laporan Penelitian Lapangan Pendekatan Kualitatif Dan Kuantitatif”. (Skripsi Tesis, Dan Disertasi). 